\title{
TEORIJA POJMOVNOG OBJEDINJAVANJA PREMA TEORIJI POJMOVNIH METAFORA: SPECIFIČNOSTI I PRIMENA U JEZIČKOJ ANALIZI
}

\begin{abstract}
Ovaj rad se bavi dvema važnim teorijama u kognitivnolingvističkom pristupu, teorijom pojmovnih metafora, koja objašnjava konvencionalne načine razmišljanja i jezičkog izražavanja, i teorijom pojmovnog objedinjavanja, koja je usmerena na mentalnu i jezičku kreativnost, tj. konstruisanje ili izvođenje značenja u samom trenutku komuniciranja. Budući da se ove dve teorije često smatraju rivalskim, jer jednim delom objašnjavaju iste fenomene, najopštiji cilj ovoga rada jeste da ukaže na specifičnosti teorije pojmovnog objedinjavanja u odnosu na teoriju pojmovnih metafora. Drugim rečima, cilj ovoga rada je da se opišu, prikažu i ilustruju sličnosti, i posebno različitosti ove dve teorije u pogledu mehanizma, tipova pojmovno-jezičkih pojava koje opisuju, i načina na koje ih opisuju, kao i da se predstave kroz ključne primere na srpskom jeziku. Ove dve teorije razlikuju se po sledećim kriterijumima: kognitivna shema, tip značenja, izvođenje nameravanog značenja, komunikativna svrha, pristup analizi podataka i tipične jezičke strukture. Uporedna analiza pokazuje da obe teorije objašnjavaju metaforičke izraze, pri čemu teorija pojmovnih metafora na direktniji i jednostavniji način objašnjava konvencionalne metaforičke izraze, dok teorija pojmovnog objedinjavanja preciznije objašnjava kreativne metafore. Pored ovoga, samo teorija pojmovnog objedinjavanja objašnjava druge aspekte mentalne i jezičke kreativnosti oličene tipično kroz morfološke slivenice, složenice, polusloženice i imeničke sintagme, reči sa širokim obuhvatom značenja i kontrafaktive.
\end{abstract}

Ključne reči: teorija pojmovnih metafora, teorija pojmovnog objedinjavanja, sličnosti, razlike, konvencionalnost, kreativnost, jezičke strukture.

\footnotetext{
*\$sonjafk20@gmail.com

** Rad je napisan u okviru projekta Jezici $i$ kulture u vremenu i prostoru (br. 178002), koji finansira Ministarstvo prosvete, nauke i tehnološkog razvoja Republike Srbije.
} 


\section{Uvod}

Kognitivna lingvistika, koja, najopštije rečeno, izučava odnos između jezika, uma i socio-fizičkog iskustva, nastala je u kasnim 70-im i ranim 80-im godinama 20. veka kao reakcija na generativnu gramatiku, prema kojoj je jezičko znanje posebno, odvojeno od ostalih kognitivnih sposobnosti, a naglasak je na formalnoj sintaksičkoj analizi. Suprotno tome, u kognitivnoj lingvistici smatra se da je jezičko znanje deo opštih kognitivnih sposobnosti, a značenje je enciklopedijsko i na nivou pojmova, a ne jezika, te jezik samo odražava ili signalizira značenja sadržana u pojmovima. Ovakav pristup, po kome je jezik u neraskidivoj vezi sa kognicijom, prvenstveno je pronikao iz radova Lakoffa (1987, 1993), Langackera (1987, 1991) i Talmyja (2000). Kognitivna lingvistika predstavlja holistički pristup izučavanju jezika i obuhvata nekoliko važnih teorija, a neke od njih jesu: teorija pojmovnih metafora (Lakoff, Johnson, 1980/2003), teorija pojmovnih metonimija (Radden, Panther, 1999; Panther, Thornburg, 2000), teorija mentalnih prostora (Fauconnier, 1985, 1997) i teorija pojmovnog objedinjavanja (Fauconnier,Turner, 2002). Najopštije rečeno, cilj ovoga rada jeste da ukaže na specifičnosti teorije pojmovnog objedinjavanja u odnosu na teoriju pojmovnih metafora. Konkretnije, cilj je da se opišu, prikažu i ilustruju sličnosti, i posebno razlike ove dve teorije u pogledu mehanizma, tipova jezičkih pojava koje opisuju, i načina na koje ih opisuju, kao i da se predstave kroz ključne primere na srpskom jeziku. U radu se daje pregled kriterijuma po kojima se ove dve teorije razlikuju, a to su kognitivna shema, tip značenja, izvođenje nameravanog značenja, komunikativna svrha, pristup analizi podataka i tipične jezičke strukture u teoriji pojmovnog objedinjavanja.

\section{Dve kognitivnolingvističke teorije}

Kao što je već naznačeno, kognitivna lingvistika jeste jedan pristup jeziku u neraskidivoj spezi sa kognitivnim mehanizmima, u okviru koga se izrodilo nekoliko važnih teorija. Pomenute teorije, najopštije rečeno, mogle bi se podeliti u dve kategorije, one koje se prvenstveno bave stabilnim, ukorenjenim obrascima razmišljanja, kao što su teorije pojmovnih metafora i metonimija, i one koje se bave novim značenjem, tj. aktivnim stvaranjem značenja na licu mesta u trenutnom komunikacionom događa- 
ju, kao što su teorije mentalnih prostora i pojmovnog objedinjavanja. U ovom radu akcenat je na opisivanju teorije pojmovnog objedinjavanja, kao i jezičkih fenomena koje ona objašnjava u odnosu na teoriju pojmovnih metafora, kao prve najvažnije teorije u kognitivnoj lingvistici. U nastavku će ukratko biti opisani mehanizmi ovih teorija, što će poslužiti kao baza za ukazivanje na njihove različitosti u primeni u jezičkoj analizi.

\subsection{Teorija pojmovnih metafora}

Teorija pojmovnih metafora (Lakoff, Johnson, 1980/2003) jedna je od najuticajnijih teorija u kognitivnolingvističkom okviru, a bavi se kognitivnim strukturama ukorenjenim u dugoročnoj memoriji i njihovim realizacijama u jezičkom izrazu. Prema ovoj teoriji, metafora predstavlja važan mehanizam za organizovanje čovekovog pojmovnog sistema, posmatra se kao kognitivni fenomen, kao način na koji čovek interpretira svet i organizuje iskustvo, a ne samo kao jezički, stilski fenomen. Pojmovna metafora je mehanizam putem kojeg se jedan pojam ili pojmovni domen, ciljni domen, koji je tipično apstraktan i čulno nesaznatljiv razume pomoću drugog pojma, izvornog pojma, koji je obično čulno saznatljiv i dobro poznat, i to putem jednosmernog preslikavanja odgovarajućih elemenata strukture izvornog pojma na ciljni (Lakoff, Johnson 2003: 5; Klikovac, 2004: 1112, 14; Kövecses 2010: 4-9). Ovaj mehanizam predstavlja se u vidu formule A JE B, tj. CILJNI DOMEN JE IZVORNI DOMEN. U nastavku će biti prikazani neki od uobičajenih metaforičkih prenosa u mnogim jezicima sveta, a za ilustraciju će biti uzeti primeri iz srpskog jezika. Na primer, uobičajeno je da se o uspehu ili društvenom statusu razmišlja i govori putem vertikalne dimenzije, što se beleži pojmovnim metaforama POVOLJAN POLOŽAJ U DRUŠTVU JE GORE, NEPOVOLJAN POLOŽAJ U DRUŠTVU JE DOLE: On sigurno ne zaslužuje tako visoko mesto u društvu. Zar bi on prihvatio tako nizak položaj? (Rasulić, 2003: 241-242). Zatim, Klikovac (2003: 222-223) pokazuje da čovek konceptualizuje svoje postojanje u vremenu pomoću pojma SADRŽAVANJA, pri čemu su aktivne dve metafore VREME JE PROSTOR i VREMENSKE JEDINICE SU SADRŽATELJI ZA ČOVEKA: ... tek smo u godini trideset $i$ sedmojosmoj ... $\underline{i z}$ dana $\underline{u}$ dan, $\underline{i z}$ godine $\underline{u}$ godinu. Takođe, o shvatanju nečega razmišlja se putem konkretnih čulnih doživljaja, što se beleži metaforom BITI SVESTAN NEČEGA JE VIDETI/OSEĆATI/ MIRISATI, i sl. Na primer: $\check{C} u o$ sam $d a$ 
imaš neki problem. Okusio sam i ja kako je teško živeti kao siromah. U oba primera, značenje glagola čuti i okusiti je 'razumeti/shvatati' (Cvetković, 2006: 281-282). Takođe, veoma česte su i metafore kojima se sreća i tuga konceptualizuju kroz vertikalnu dimenziju, npr. SREĆA JE GORE: Bio je $\underline{n a}$ sedmom nebu. To mu je podiglo raspoloženje. (Klikovac, 2004: 23).

\subsection{Teorija pojmovnog objedinjavanja}

U teoriji pojmovnog objedinjavanja, ${ }^{1}$ koju su razvili Fauconnier i Turner (2002), u fokusu su kognitivnolingvistički postulati prema kojima je značenje enciklopedijsko, a izvođenje značenja se zasniva na određenim konceptualizacijama (detaljnije o svim postulatima videti u Evans, Green, 2006: 157-162). Da pojasnimo, budući da je značenje enciklopedijsko, ono je sadržano u pojmovima, a jezičke strukture su samo indikatori za aktiviranje različitih pojmovnih operacija i vanjezičkog znanja radi izvođenja značenja (Evans, Green, 2006: 157-163). Stoga, značenje se aktivno stvara, odnosno treba ga izvesti, i to na osnovu pojmovnih struktura, njihove organizacije, kao i vanjezičkog znanja. Izvođenje značenja podrazumeva specifičnu integraciju novonastale strukture, koja je više od zbira njenih pojedinačnih delova. Ova teorija prvobitno je nastala s ciljem da objasni egzotične, kreativne aspekte jezika i značenja, kao što su nove metafore i kontrafaktivi; međutim, sada njeni zagovornici smatraju da je pojmovno objedinjavanje osnovni mehanizam u ljudskom razmišljanju i zamišljanju (Fauconnier, Turner, 2002: 37). Model ove teorije podrazumeva specifična preslikavanja i projekcije između više mentalnih prostora. Model osnovne mreže pojmovnog objedinjavanja obuhvata četiri mentalna prostora: najmanje dva ulazna prostora, jedan stopljeni prostor ili amalgam, koji sadrži selektivne i parcijalne projekcije elemenata i odnosa iz ulaznih prostora koji se objedinjuju na takav način da proizvode novu strukturu, koja kao takva ne postoji ni u jednom od ulaznih prostora. Sve njih natkrijuje generički prostor, izrazito apstraktna, shematska struktura koja obuhvata sve ostale mentalne prostore, poput zajedničkog sadržatelja, te omogućava njihovo objedinjavanje. Pojmovno stapanje je operacija koja otpočinje međuprostornim preslikavanjem veza između elemenata-

1 Srpski termini u vezi sa teorijom pojmovnog objedinjavanja dati su prema Rasulić, Klikovac (2014: 337-416). 
parnjaka iz različitih ulaznih prostora. Preslikavanja se mogu zasnivati na različitim tipovima odnosa kao što su istovetnost, vreme, prostor, transformacija, promena, sličnost, analogija, metafora, metonimija (posebno odnosi: uzrok-posledica i deo-celina), i na drugim presudno važnim odnosima (detaljno o ovome videti u Fauconnier, Turner, 2002: 92-102). Potom se određeni elementi i odnosi iz ulaznih prostora projektuju u stopljeni prostor ili amalgam u zavisnosti od konkretnog konteksta u kome se odvija komunikacija. Proces pojmovnog objedinjavanja često se grafički predstavlja pomoću dijagrama, pri čemu su mentalni prostori naznačeni kao krugovi, elementi i odnosi tačkama, međuprostorna preslikavanja kao pune linije između mentalnih prostora, dok su projekcije iz generičkog prostora u ulazne prostore, kao i projekcije iz ulaznih prostora u amalgam predstavljene isprekidanim linijama (vidi dijagram 1):

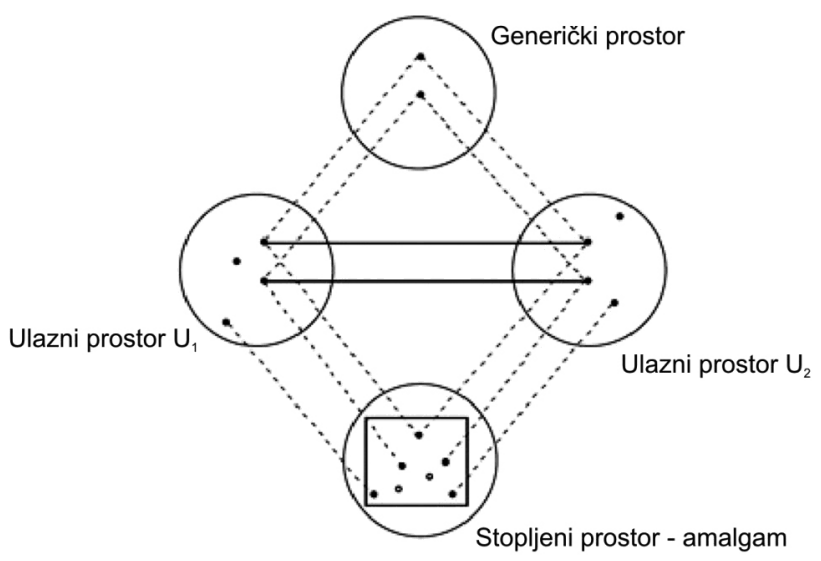

Dijagram 1: Osnovna mreža pojmovnog objedinjavanja (prema Fauconnier,Turner, 2002: 46)

Proces pojmovnog objedinjavanja biće ilustrovan na neologizmu pica-burek u srpskom jeziku (primer iz Filipović Kovačević, 2011: 252). Na osnovu generičkog prostora koji sadrži hranu s nadevom uspostavljaju se preslikavanja između ekvivalentnih elemenata iz ulaznog prostora Pica: pica, okruglo, nemasno, pljosnato testo, nadev: šunka, sir, pečurke, kečap (odgore), i ulaznog prostora Burek: masno testo od zgužvanih kora, nadev: 
sir, meso ili krompir (unutra, u testu). U amalgam se projektuje semantički okvir iz ulaznog prostora Burek, jer se radi o hrani s masnim testom od izgužvanih kora s nadevom u samom testu, dok se iz ulaznog prostora Pica projektuje sam nadev: šunka, sir, pečurke, kečap, te i takav ukus. Picaburek je pojmovni amalgam nastao kao rezultat projekcija u amalgam iz dva ulazna prostora, tj. burek sa nadevom tipičnim za picu, te je u nekom smislu istovremeno i burek i pica.

\section{Specifičnosti teorije pojmovnog objedinjavanja u odnosu na teoriju pojmovnih metafora}

Teorije pojmovnih metafora i pojmovnog objedinjavanja jednim delom analiziraju i objašnjavaju iste jezičke fenomene - prenesena, tj. metaforička, značenja jezičkih izraza, ali u tu svrhu koriste drugačiju teorijskometodološku aparaturu.

Dve upoređene teorije slične su po sledećim kriterijumima: (1) jezičke pojave kojima se bave tretiraju kao pojmovne fenomene, (2) podrazumevaju sistematsko preslikavanje materijala između kognitivnih struktura i definišu ograničenja preslikavanja, i (3) objašnjavaju metaforičke jezičke izraze. Međutim, ove dve teorije ipak se značajno razlikuju u okviru određenih karakteristika, što će u nastavku biti naglašeno, objašnjeno i ilustrovano. Kriterijumi po kojima se razlikuju jesu: kognitivna shema, tip značenja, izvođenje nameravanog značenja, komunikativna svrha, pristup analizi podataka i tipične jezičke strukture u teoriji pojmovnog objedinjavanja.

\subsection{Kognitivna shema}

Pod razlikama u kognitivnoj shemi misli se na kognitivne strukture $\mathrm{u}$ okviru kojih se odvijaju procesi metaforičkog prenosa i pojmovnog stapanja.

(a) Osnovne kognitivne strukture. Ove dve teorije operišu sličnim, ali ipak različitim, specifičnim kognitivnim elementima u svojim mehanizmima ispoljavanja. Prva razlika se tiče pojmovnog domena i mentalnog prostora, kao osnovnih kognitivnih struktura od kojih počinju mentalne operacije. U osnovi teorije pojmovne metafore jeste pojmovni domen, najšire definisan kao koherentna organizacija iskustva (Kövecses 2010: 4), a konkretnije, kao shematizacija iskustva na pojmovnom nivou, u dugoročnoj memoriji, koja povezuje elemente i entitete koji pripadaju jednom 
konkretnom kulturološkom scenariju, situaciji ili događaju iz ljudskog iskustva. Na primer, domen PUTOVANJA obuhvata i povezuje putnike, prevozna sredstva, put, odredišta, prepreke na putu i sl. (Evans, Green, 2006: 211). Lakoff $(1987,2003)$ koristi ovako definisan pojmovni domen u svrhu objašnjavanja metaforičkih i metonimijskih preslikavanja. ${ }^{2}$

$\mathrm{S}$ druge strane, u osnovi teorije pojmovnog objedinjavanja jeste mentalni prostor, uveden u teoriji mentalnih prostora, kao modelu dinamičkog konstruisanja značenja (Fauconnier 1985/1994, 1997). Suština ove teorije je da ljudi prilikom razmišljanja i govorenja razdeljuju složeni diskurs na delove, tj. mentalne prostore radi uspešne komunikacije. Mentalni prostor je ,(relativno mali) pojmovni segment stvoren radi lokalnog razumevanja i delovanja" (Turner, Fauconnier, 1995: 184) ili, drugačije rečeno „mala pojmovna celina koja nastaje u toku mišljenja i govorenja za potrebe neposrednog razumevanja" (Rasulić 2004: 180). Reči onlajn i neposredno naglašavaju da su mentalni prostori trenutno stvorene pojmovne strukture koje nastaju u samoj komunikaciji, a na osnovu opšteg jezičkog i vanjezičkog znanja, i obavezno, datog konteksta. Kao takav, mentalni prostor je uži ili konkretniji konstrukt od pojmovnog domena, budući da je jedinstven i privremen segment pojmovne strukture koja nastaje tokom samog komunikacionog događaja radi razumevanja poruke, te je samo deo opštije strukture uskladištene u dugoročnoj memoriji, odnosno pojmovnog domena. Na primer, mentalni prostor za iskaz Dobro sam se opekao u poslovanju s njim preuzima deo strukture iz domena TEMPERATURE u vezi sa pojmom VRELINE i bola prilikom kontakta sa vrelom materijom, kao i domena POSLOVNA TRANSAKCIJA sa elementima: poslovni dogovor, ugovarač posla, izvršilac posla, posao, naknada. Kövecses (2006: 250) slikovito opisuje mentalne prostore kao male sijalice koje se pale u mozgu, pri čemu upaljena lampica odgovara aktivnom mentalnom prostoru.

(b) Mehanizmi projekcija i preslikavanja. U teoriji pojmovne metafore prisutna su samo dva pojmovna domena, izvorni, koji je konretan, opipljiv, i ciljni, koji je apstraktan, a preslikavanja su obavezno jednosmerna, od izvornog ka ciljnom domenu (Ovo je opisano u § 2.1.). S druge stra-

2 Langacker (1987) se takođe bavi pojmovnim domenom, ali ga tretira unekoliko drugačije, prvenstveno kao koherentan sistem pojmova povezanih na određeni način, čija je svrha da omogući razumevanje pojedinačnih leksičkih pojmova. Na primer, da bismo razumeli pojmove VRUĆE, TOPLO, MLAKO, HLADNO, moramo poznavati domen TEMPERATURE. 
ne, u teoriji pojmovnog objedinjavanja pojmovne projekcije su složenije, budući da učestvuju tipično četiri mentalna prostora, pri čemu dolazi do preslikavanja, $\mathrm{tj}$. uspostavljanja odnosa ekvivalencije između odgovarajućih elemenata iz ulaznih prostora, a potom do jednosmerne i selektivne projekcije sadržaja iz ulaznih prostora $u$ amalgam, gde se obrazuje novonastala struktura sa novim značenjem (Ovo je opisano u $\S$ 2.2.).

\subsection{Tip značenja}

U vezi sa tipom značenja koje objašnjavaju teorije pojmovnih metafora i objedinjavanja mogu se izdvojiti dve važne dihotomije: (a) konvencionalno naspram novog značenja, i (b) metaforičko naspram drugih tipova značenja. Naime, teorija pojmovnih metafora objašnjava konvencionalne, uobičajene načine razmišljanja i pojmovne veze između konkretnog i apstraktnog kod metaforičkih prenosa značenja. Na primer, u srpskom jeziku o onome što je veoma dobro ili kvalitetno razmišlja se putem konkretnih pojmova kao što su, vertikalna dimenzija, tj. visina, svetlost, veličina, što se izražava sledećim pojmovnim metaforama: VEOMA DOBRO JE GORE/VISOKo (Ovaj film je vrh. Posao uradjen vrhunski.); VeOMA DOBRo JE SVETLOST ( briljantan pisac, sjajan student); VEOMA DOBRO JE VELIKO (veličanstven govor, mega bend) (primeri su iz Filipović Kovačević, 2012: 244, 246, 248). Nadalje, kroz CRVENO, kao pojam jedne konkretne boje, u srpskom jeziku izražava se bes, ali i poseban status, što se beleži sledećim pojmovnim metaforama: BESAN JE CRVEN (Od besa je bio crven kao rak/paprika.); IMATI POSEBAN STATUS JE BITI NA CRVENOM TEPIHU (Pred njom su prostirali crveni tepih.) (primeri su iz Filipović Kovačević, 2015: 125-126), dok se, na primer, ružičastom bojom izražava ono što je izuzetno dobro: NEREALNO DOBRO JE RUŽIČASTO (Ona gleda na život kroz ružičaste naočare.) (primeri su iz Filipović Kovačević, 2015: 128). Ilustracije radi, daćemo još jedan primer; naime, o onome što je važno i vredno razmišlja se kao o nečem fizički velikom, dok se o nevažnom razmišlja kao o fizički malom: vAŽNO/ VREDNO JE VELIKO (velika zverka, krupna riba su izrazi za 'moćnog čoveka', imati velike planove), NEVAŽNO/BEZVREDNO JE MALO (sitna riba, osećati se malo, tj. 'bezvredno') (primeri su preuzeti iz Filipović Kovačević, 2013: 529-530, 532). Navedenim primerima pokazano je da su pojmovne metafore uvreženi i duboko usađeni načini razmišljanja, pa onda i izražavanja 
u različitim jezicima i kulturama, zbog čega u najvećem broju jezičkih izraza govornici i ne primećuju da su u pitanju prenesena značenja budući da je to uobičajen, tj. „normalan” način izražavanja.

S druge strane, teorija pojmovnog objedinjavanja naglašava i objašnjava dinamičke aspekte značenja, odnosno nove i jedinstvene slučajeve konceptualizacije koji nisu dubinski usađeni u dugoročnoj memoriji kao uobičajeni načini razmišljanja. Na primer, ova teorija objašnjava slučajeve neologizama, kao što je krofnatorija, što je naziv jedne prodavnice specijalizovane za prodaju različitih vrsta krofni (krofna + laboratorija), picaburek, tj. burek sa nadevom tipičnim za picu (sir, kečap, šunka, pečurke) (Filipović Kovačević, 2011: 252), metaforičke, nelogične iskaze tipa Ovaj hirurg je mesar, čime se izražava 'nekompetentnost' hirurga (Fauconnier, Turner, 2002: 297-298) i još mnogo interesantnih, neočekivanih jezičkih i logičkih struktura (o tipičnim jezičkim strukturama koje objašnjava teorija pojmovnog objedinjavanja biće reči u § 3.6.). Pojmovno stapanje podrazumeva „dešifrovanje” značenja na licu mesta, pri čemu se ulaže veći kognitivni napor budući da se ne poseže automatski za ukorenjenim obrascima i strukturama razmišljanja. Tako, da bismo razumeli šta znači krofnatorija, mi posežemo za znanjem koje imamo o krofnama, kao i za znanjem koje imamo o laboratoriji, kao mestu gde se izvode eksperimenti, te ukrštanjem ta dva domena znanja konstruišemo značenje, tj. zaključujemo da je u pitanju mesto gde se eksperimentiše sa krofnama, tj. gde ima mnogo krofni različitog ukusa.

Druga dihotomija odnosi se na činjenicu da teorija pojmovnih metafora objašnjava isključivo metaforička značenja, dok je teorija pojmovnog objedinjavanja znatno obuhvatnija budući da objašnjava metaforička značenja, i to nova, kreativna (kao što se vidi u primeru Ovaj hirurg je mesar), ali i metonimijska (npr. To je Ana, pri čemu se misli na Anin glas koji čujemo, On ima Pikasa u radnoj sobi), kontrafaktivna (npr. Da sam na tvom mestu, ja bih zaposlio mene ${ }^{3}$ ), i šire, sva složena značenja koja podrazumevaju kombinovanje ili stapanje različitih pojmova u jednu novu značenjsku celinu (ovo je ilustrovano primerima krofnatorija i pica-burek). ${ }^{4}$

3 Primer je dat prema Fauconnier (1997: 161): If I were you, I would hire me.

$4 \quad$ U narednim pododeljcima u radu detaljnije će biti prikazano izvođenje značenja iz perspektive teorije pojmovnog objedinjavanja u metaforičkim, metonimjskim i kontrafaktivnim primerima. 


\subsection{Izvođenje nameravanog značenja}

U teoriji pojmovne metafore nameravano, implicirano značenje izvodi se direktnim prenosom određenih osobina i odnosa iz izvornog domena na ključni entitet u ciljnom domenu, što će biti ilustovano primerima koji potvrđuju princip jednosmernosti. Lakoff i Turner (1989) tvrde da princip jednosmernosti važi čak i kada se čini da je u pitanju jedna metafora koja funcioniše u dva smera. Stoga, postoje dve pojmovne metafore sa domenima ČOVEK i MAŠINA, jer se u njima preslikavaju različiti elementi i kvaliteti. Na primer, u osnovi iskaza On je mašina i Doživeo je nervni slom jeste metafora ČOVEK JE MAŠINA, jer se karakteristike mašina, kao što su brzina, automatizam, bezgrešnost, efikasnost u prvom primeru, i činjenica da se mašina može fizički slomiti ili pokvariti, u drugom, prenose na čoveka. S druge strane, u osnovi iskaza Moj auto neće da krene i Moj kompjuter neće da radi jeste pojmovna metafora MAŠINA JE ČOVEK, jer dolazi do preslikavanja ljudske karakteristike, volje, na automobil i kompjuter (primeri su dati po analogiji sa engleskim izrazima u Evans, Green, 2006: 297).

U teoriji pojmovnog objedinjavanja nameravano značenje izvodi se iz amalgama, tj. stopljenog prostora, u kome je novonastala struktura, koja je rezultat neobičnog, često nekongruentnog kombinovanja elemenata i odnosa iz ulaznih prostora. Naime, ova teorija pokazuje da je značenje suštinski nekompoziciono, tj. da podrazumeva integraciju struktura, pri čemu rezultat nije njihov prost zbir, već više od toga, tj. neko novonastalo značenje, koje je donekle izmenjeno i ima sebi svojstvenu strukturu (Turner, Fauconnier, 1995: 189-192), a nalazi se u amalgamu. Turner i Fauconnier (1995) smatraju da su složene reči i spojevi reči u svojim nekompozicionim značenjima pravilnost u jeziku, a ne sporadični i egzotični primeri, te da se slučajevi kompozitivnosti, tj. značenja izvedenog prostim sabiranjem osnovnih rečničkih definicija, mogu objasniti samo postojanjem izrazitih uobičajenih slučajeva. S tim u vezi Turner i Fauconnier (1995) navode primer crvena olovka, koji na prvi pogled smatramo kompozicionim. Međutim, oni pokazuju da ovaj sintagmatski spoj može da označi 'olovku koja piše crveno' (kompoziciono), ali i ‘olovku sa crvenom drškom', i ‘olovku umazanu crvenim karminom', i ‘olovku kojom se označava minus u finansijskom smislu', itd. Dakle, značenje se mora izvesti i to tako da bude u skladu sa kontekstom u datoj komunikacionoj situaciji. 


\subsubsection{Izvođenje metaforičkog značenja}

Teorija pojmovnog objedinjavanja objašnjava i metaforičke jezičke izraze, što je polje u kome se preklapa sa teorijom pojmovne metafore. Ovde se mogu razlikovati dve osnovne kategorije: konvencionalni i nekonvencionalni, tj. kreativni metaforički izrazi. Prvu kategoriju veoma uspešno opisuje teorija pojmovnih metafora. Naime, ustaljeni jezički izrazi, koje i ne percipiramo kao metaforičke, zapravo često u osnovi imaju pojmovne metafore kao ustaljene obrasce razmišljanja. Na primer, sledeće iskaze ne bismo smatrali posebno slikovitim ili pesničkim, već uobičajenim načinima za razgovor o životu: On neće dozvoliti da mu se nešto ispreči na putu. Daleko je stigao u životu. Međutim, u njihovoj osnovi je konvencionalna pojmovna metafora ŽIVOT JE PUTOVANJE, a konvencionalna jednosmerna metaforička preslikavanja iz izvornog na ciljni domen objašnjavaju navedene izraze: putnik $\rightarrow$ osoba koja živi život, putovanje/kretanje (prema odredištu) $\rightarrow$ život (sa svrhom), odredištelcilj $\rightarrow$ svrha života, prepreke (pri kretanju) $\rightarrow$ problemu $(u$ životu), pređen put $\rightarrow$ napredovanje, staza/put (na putovanju) $\rightarrow$ način života, izbor puta $\rightarrow$ životni izbor (Kövecses 2006: 116). Prvi primer objašnjava preslikavanje prepreke (pri kretanju) $\rightarrow$ problemu ( $u$ životu), a drugi primer odredište $\rightarrow$ svrha života.

Teorija pojmovnog objedinjavanja može da objasni ovakve slučajeve, ali bi to podrazumevalo složeniji proces koji uključuje četiri mentalna prostora i novonastalu strukturu u amalgamu, što je komplikovanije i nepotrebno budući da teorija pojmovnih metafora daje jednostavnije konkretno tumačenje.

Međutim, teorija pojmovnog objedinjavanja daje bolja, tj. preciznija tumačenja kada su u pitanju novi, kreativni metaforički izrazi. Na primer, u pesmi Prljavog kazališta poznati refren glasi: Zaustavite Zemlju, silazim

Nije mi do ničeg, odlazim...

U pitanju je konvencionalna metafora ŽIVOT JE PUTOVANJE, ali se koristi nekonvencionalan jezički izraz zasnovan na nekonvencionalnom preslikavanju: odlaženje/silaženje s puta $\rightarrow$ kraj života ili kraj jedne životne faze. Teorija pojmovnih metafora ovo objašnjava mehanizmom proširivanja metafore, koji podrazumeva unošenje novog, dodatnog pojmovnog elementa u izvorni domen, a u ovom slučaju to je silaženje sa puta, tj. Zemlje, prilikom putovanja. Međutim, u interpretaciji teorije pojmovnog 
objedinjavanja daje se konkretna slika jezičkog izraza. U osnovi pojmovnog stapanja često se nalazi konvencionalna pojmovna metafora kao okidač za uspostavljanje veze između ulaznih prostora, a u ovom slučaju to je ŽIVOT JE PUTOVANJE. U ulaznom prostoru Život jeste čovek koji živi svoj život na određeni način, ali život mu je ispunjen problemima i konfliktima; na kraju svog životnog veka on umire. U ulaznom prostoru Putovanje čovek putuje po celoj planeti Zemlji, i u jednom trenutku, pre krajnjeg odredišta, on silazi sa puta i prekida putovanje. U amalgamu je čovek koji živi i u jednom trenutku, pre starosti, silazi sa Zemlje, što stvara novonastalo značenje: prisilno prekida svoj život ili napušta dotadašnji način života.

Nadalje, teorija pojmovnih metafora ne može precizno objasniti nameravana značenja nekih metaforičkih iskaza. Često navođen primer ovog tipa jeste Ovaj hirurg je mesar (Fauconnier, Turner, 2002: 297-298), čije značenje je 'nekompetentnost hirurga'. Ovo značenje ne proizlazi iz analize u okvirima teorije pojmovne metafore, gde se elementi iz izvornog domena MESAR preslikavaju na ciljni domen HIRURG: mesar $\rightarrow$ hirurg, mesarski nož $\rightarrow$ skalpel, mrtva životinja $\rightarrow$ pacijent, tranžiranje $\rightarrow$ operacija. Ne može se reći da su mesari neodgovorni i nekompetentni u poslu koji rade. Njihovo zanimanje podrazumeva stručnost i veštinu, kao i poznavanje anatomije pojedinih životinja i određnih vrsta mesa. Međutim, značenje nekompetentnosti objašnjava teorija pojmovnog objedinjavanja: u amalgamu dolazi do nesklada između cilja: lečenja iz ulaznog prostora Lekar i sredstva, tj. postupka iz ulaznog prostora Mesar: mesarskog noža i tranžiranja. Dakle, operacija se izvodi neprimerenim sredstvom, mesarskim nožem. Sličan je primer iz serije Istine i laži u kome mlad čovek koji dresira pse uspeva da oraspoloži jednu zabrinutu i tužnu ženu, na čemu mu se ona zahvaljuje, a on odgovara: Šta ćeš, ja sam rođeni klovn. Implicirano značenje je 'Ja sam zabavan', a teorija pojmovnog objedinjavanja to objašnjava neskladom u amalgamu između cilja komuniciranja između dve odrasle osobe - rešavanje problema ozbiljnim razgovorom, s jedne strane, i načina i efekta komunikacije tipične za klovna - glupiranje radi zabavljanja. Još neki od sličnih iskaza su, na primer: Ovaj službenik je pravi kočijaš. Ova žena je pravi kauboj. Radden i dr. (2007: 5-9) ovakve pojave kategorišu kao slučajeve semantičke nepotpunosti ili hipospecifikovanosti (srpski termini su prema Prćiću, 2008: 292), tj. strukturama naizgled bez značenja, i naglašavaju da one zahtevaju pojmovno nadograđi- 
vanje (2007: 5-9). Postoje tri tipa semantičke nepotpunosti - implicitnost, neodređenost i inkompatibilnost. U osnovi ovde navedenih metaforičkih iskaza jeste inkompatibilnost (o drugom tipu semantičke nepotpunosti videti u §3.6.3).

\subsubsection{Izvođenje metonimijskog značenja}

Važno je naglasiti da teorija pojmovnog objedinjavanja objašnjava i metonimijska značenja. Naime, pojmovna metonimija je kognitivni mehanizam pomoću kojeg jedan, konkretniji, istaknutiji, pojam - sredstvo, omogućuje mentalni pristup drugom, apstraktnijem, manje istaknutom ciljnom ројти, i to u jednom istom pojmovnom domenu. Izražava odnos B UMESTO A i zasniva se na pojmovnoj bliskosti, odnosno fizičkoj ili uzročnoj povezanosti (Evans i Green 2006: 311). Tako, kada konobar kaže Sendvič sa šunkom je za stolom broj 7 (eng. The ham sandwich is at table 7), ${ }^{5}$ on koristi pojam hrane - sendvič sa šunkom, koji je mušterija naručila, a misli, zapravo, na mušteriju, jer je iz njegove perspektive važna narudžbina. Kövecses i Radden (1998: 37-77) iscrpno se bave pojmovnom metonimijom, pri čemu konstatuju niz metonimijskih odnosa (npr. DEO UMESTO CELINE: kaže se Engleska, a misli se na Veliku Britaniju, PROIZVOĐAČ UMESTO PROIZVODA: Kupio sam Renoa, AUTOR UMESTO DELA: Volim da čitam Šekspi$\underline{r a}, \ldots)$. Međutim, Alač i Coulson (2004) pokazuju da se sama pojmovna metonimija može posmatrati kao integracija između pojmova koji predstavljaju sredstvo i cilj, što ilustuju primerom On ima Pikasa u radnoj sobi (Alač, Coulson, 2004: 23-4). Tu su prisutna dva ulazna prostora: Pablo Pikaso, sa elementom Pikaso, kao umetnik, koji se povezuje sa već postojećim znanjem o Pikasovoj koncepciji umetnosti, o njegovoj tehnici, ulozi u istoriji slikarstva, i sl., i Pikasova umetnička dela sa elementom koji predstavlja jednu Pikasovu sliku u radnoj sobi, ali tu je i već postojeće znanje o njegovim drugim slikama (Gernika, Dečak sa lulom, Devojka ispred ogledala ,...). Uspostavljaju se preslikavanja između ulaznih prostora, $\mathrm{tj}$. između Pikasa i njegovog dela, a na osnovu pragmatičke veze kojom se stvaralac povezuje sa proizvodom svog stvaranja. U stopljeni prostor ili amalgam selektivno se projektuju važni elementi iz oba ulazna prostora (npr. nije važno to što je Pikaso bio član Komunističke partije). Novona-

Primer je naveden prema Alač, Coulson (2004: 21). 
stala struktura sa novim značenjem nastaje kao rezultat stapanja Pikasove koncepcije umetnosti, njegove tehnike i uloge u istoriji umetnosti, iz prvog ulaznog prostora, i njegove slike, iz drugog ulaznog prostora. Novonastalo značenje se tiče značaja ove konkretne slike zbog veze sa tako značajnim umetnikom, te shvatamo da reč Pikaso ne predstavlja samo sliku, nego i koncepciju slike u vezi sa tako značajnim umetnikom. U amalgamu je došlo da komprimovanja uzroka (umetnika) i posledice (umetničkog dela) tako da je reakcija na umetničko dela neodvojivo povezana sa poštovanjem prema umetniku. Ideju o metonimiji kao o jednom tipu pojmovnog objedinjavanja ističe i razrađuje Rasulić (2006: 307-317) u radu u kom se bavi metonimijskim odnosom tipa OSOBA UMESTO x u srpskom i engleskom jeziku.

\subsection{Komunikativna svrha}

Kognitivni mehanizmi kojima se bave dve upoređene teorije imaju drugačiju komunikativnu svrhu. Svrha metafore je da se apstraktno predstavi kao konkretno ili čulno saznatljivo radi lakšeg razumevanja. Na primer, kada se za nekoga kaže da je kao guska u magli, tj. da se ponaša 'bez plana, nepripremljeno, nepromišljeno, nasumice' ili da mu se pomutio mozak/razum, tj. 'da se neko zaludeo nečim, da je izgubio sposobnost da normalno razmišlja' (Filipović Kovačević, 2018: 152-153) u osnovi je zapravo pojmovna metafora IRACIONALAN ČOVEK JE U NEPROVIDNOJ MATERIJI, jer onaj ko je obavijen maglom ili je u drugoj mutnoj materiji ne vidi dobro, pa samim tim i ne razume stvari, tj. iracionalan je (ovde je prisutna i metafora RAZUMeVANJE JE VIĐENJe, tj. NeRAZUMEVANJE JE LOŠE VIĐENJE). Drugi ilustrativan primer je On ima vatrenu narav, u značenju 'sklon je eksplozivnim, besnim reakcijama', u čijoj osnovi je metafora BES JE VATRA. Takođe, iskaz Njih dvoje su posebno bliski u značenju 'emotivno povezani' zasniva se na pojmovnoj metafori EMOTIVNA BLISKOST JE FIZIČKA BLISKOST. U svim navedenim slučajevima, mi apstraktne pojmove kao što su iracionanost, nečiji karakter i emotivna bliskost razumemo posredstvom konkretnih pojmova koji su deo našeg gotovo svakodnevnog čulnomotornog iskustva: MAGLA/ ZAMUĆENOST, VATRA/EKSPLOZIJA i BLIZINA/DODIR, prema redosledu navođenja.

$\mathrm{S}$ druge strane komunikativna svrha pojmovnog objedinjavanja je trostruka i podrazumeva sledeće: (1) stvaranje potpuno novog, nekompozicionog značenja, (2) postizanje visokog stepena kreativnosti, ali i (3) efi- 
kasnosti, budući da se nova značenja izražavaju kroz ekonomičnu formu, tj. sažimanjem informacija na površinskom, jezičkom nivou. Na primer, istovremeno je efektnije i brže reći pica-burek nego reći opisno 'burek sa nadevom tipičnim za picu, kao što su kečap, sir, šunka i pečurke', ili krofnatorija u odnosu na opis značenja 'prodavnica specijalizovana za različite vrste krofni'. Oba navedena neologizma su kako formalni tako i pojmovni amalgami jer je konačno, novonastalo, nekompoziciono značenje specifična, nekompoziciona kombinacija elemenata iz ulaznih prostora.

\subsection{Pristup analizi podataka}

Ove dve teorije imaju drugačiji pristup analizi, kao i različite ciljeve u obradi podataka. Teorija pojmovnih metafora naglašava da postoji sistem metafora skladišten u dugoročnoj memoriji koji suštinski strukturira čovekovo iskustvo. Shodno tome, prilikom sprovođenja analize traži se sistem, tj. konvencionalni načini razmišljanja koji se odražavaju kroz razne jezičke izraze. U tom smislu u reprezentativnoj literaturi (npr. Lakoff 2003; Kövecses 2010; Ungerer, Schmid 2006) zabeležene su i objašnjene mnoge česte konvencionalne pojmovne metafore u engleskom jeziku, uobičajeni izvorni i ciljni domeni, različite konceptualizacije jednog ciljnog pojma uz ilustraciju brojnim jezičkim izrazima. Na primer: HAPPY IS UP (SREĆA JE GORE): We had to cheer him up. They were in high spirits. Lighten up.; HAPPINESS IS LIGHT (SREĆA JE SVETLOST): He radiates joy. Nothing to worry about, brighten up. She was shining with joy.; HAPPINESS IS A CAPTIVE ANIMAL (SREĆA JE UKROĆENA ŽIVOTINJA): I couldn't keep my happiness to myself. She gave way to her feelings of happiness. His feelings of joy broke loose.; SREĆA JE PROTIVNIK: She was overcome with joy. Happiness took complete control over him. He was knocked out!, ... (Kövecses 2010: 97-98). Međutim, posebni odeljci u okviru navedenih knjiga, kao i cele knjige (npr. Kövecses, 2005, 2006; Wierzbicka 1999) posvećene su razmatranjima kulturološke specifičnosti i potencijalne univerzalnosti. Pri tome, analiziraju se pojmovni i jezički nivoi, tj. ispituje se postojanje pojmovnih metafora u dva ili više jezika, ali i ekvivalentnost jezičkih izraza kojima se se one ispoljavaju. Jezici sa kojima se engleski tipično upoređuje jesu mađarski, kineski, japanski, poljski, afrički jezici poput zulua i volofa, i tahićanski jezik (koji se govori u Polineziji), budući da pripadaju genetski 
nesrodnim porodicama jezika, te slični ili isti nalazi impliciraju univerzalnost u izučavanim pojavama. Takođe, uzroci za uočene razlike traže se u širokom kulturološkom kontekstu, ali i prirodnom fizičkom okruženju, dok su najčešći domeni iskustva koji se porede sledeći: ŽIVOT, MORALNOST, VREME, EMOCIJE, a posebno LJUBAV, BES, SREĆA i TUGA. Na primer, Kövecses (2005: 36) pokazuje da metafora SREĆA JE GORE postoji u engleskom i u kineskom, što potkrepljuje primerima: (a) Ta hen gao-xing. (kineski); he very high-spirit (doslovan prevod sa kineskog na engleski); He is very high-spirited/happy. (engleski); (b)Ta xing congcong de. (kineski); he spirit rise-rise (doslovan prevod sa kineskog na engleski); His spirits are rising and rising. / He's pleased and excited. (engleski).

$\mathrm{S}$ druge strane, teorija pojmovnog objedinjavanja naglašava sam proces izvođenja novog značenja, te analizira prevashodno samu prirodu i specifičnosti pojedinačnih primera, sa akcentom na kreativnosti razmišljanja i jezičkog izraza, iako se na osnovu njih izvode i opšti principi. Stoga, u reprezentativnoj literaturi (npr. Fauconnier, 1997; Coulson, 2001; Fauconnier, Turner, 2002; Ungerer, Schmid, 2006) na mnoštvu primera iz engleskog jezika različite strukture (npr. imeničke sintagme, složenice, kontrafaktivi, ...) pokazano je kako teorija pojmovnog objedinjavanja objašnjava izvođenje značenja u kreativnim jezičkim izrazima. Specifičnost, opsežnost i dubinska analitičnost pristupa ova teorije, ilustracije radi, biće predstavljen na primeru imeničke sintagme caffeine headache ${ }^{6}$ (srp. kofeinska glavobolja), koja pokazuje kako u strukturnom smislu jednostavne imeničke modifikacije zahtevaju izvođenje značenja, koje se zasniva na složenijim kognitivnim mehanizmima poput indirektne referencije, analogije, metafore, metonimije i/ili kontrafaktivnosti, i to u zavisnosti od konteksta, pragmatičkih i diskursnih faktora. Naime kofeinska glavobolja je glavobolja prouzrokovana nekonzumiranjem jutarnje kafe. Izvođenje ovog značenja podrazumeva znanje o kofeinu kao o aktivnoj, stimulativnoj supstanci, kao i o svojstvu navikavanja na njega, ali i o posledicama navikavanja. Pojmovno objedinjavanje sastoji se iz formiranja dva amalgama, pri čemu se u jednom stapaju konkretna situacija iz prošlosti u kojoj čovek ujutru nije popio kafu i sadašnja situacija u kojoj taj čovek ima glavobolju, dok se u drugom amalgamu stapaju kontrafaktivna situacija iz 
prošlosti kada je čovek ujutru popio kafu, što je deo tipične dnevne rutine, i kontrafaktivna situacija u sadašnjosti u kojoj čovek nema glavobolju.

\subsection{Tipične jezičke strukture u teoriji pojmovnog objedinjavanja}

Budući da teorija pojmovnog objedinjavanja objašnjava širi dijapazon jezičko- pojmovnih pojava u odnosu na teoriju pojmovnih metafora, te da podrazumeva složenije procese prilikom izvođenja značenja, u nastavku će biti ukazano na tipične jezičke strukture koje aktiviraju proces pojmovnog stapanja, kao što su morfološke slivenice, složenice, imeničke sintagme, reči sa širokim obuhvatom značenja i kontrafaktivi.

\subsubsection{Morfološke slivenice}

Najočitiji primer primene teorije pojmovnog objedinjavanja jesu morfološke slivenice, nove lekseme s novim značenjima nastale od delova dve ili više leksema (Bauer, 1988: 39, 238).

Iz ugla teorije pojmovnog objedinjavanja, one predstavljaju vrhunac kreativnog formalnog i pojmovnog stapanja, budući da svaki element iz slivenice, a tipično ih ima dva, signalizira po jedan mentalni prostor, odakle se dalje odvijaju projekcije u amalgam prilikom izvođenja novog značenja. Kao primer za ovo Turner i Fauconnier (1995: 192-194) navode Chunnel, kao kombinaciju tunnel i the English Channel, tj. tunel kroz Engleski kanal, odnosno Lamanš. U srpskom jeziku, posebnu pažnju na slivanje, kao danas veoma produktivan morfološki proces i na leksičke blende, tj. slivenice, skrenuo je Bugarski (2006, 2013, 2014). On ističe da je doskora ovaj proces bio skoro nepoznat u srpskom jeziku, a Halupka Rešetar i Krstin (2009: 115) takođe konstatuju da je to nov morfološki proces u srpskom jeziku, koji je postao produktivan u poslednjih dvadesetak godina, i to posebno u domenima reklamiranja, politike i medijia. Bugarski (2009: 217) slivenice naziva i leksičkim skrivalicama budući da u sebi kriju dublja značenja, a često su odraz kreativnosti ili humora, kao na primer, čokoholičar (prema obrascu radoholičar), tj. 'onaj ko je zavisnik od čokolade'. U nastavku će biti dati primeri nekih od interesantnih novijih slivenica u srpskom jeziku: kafućino (kafa + kapućino), reč koja humoristično označava kapućino, jer je to vrsta kafe, klinceza (klinka +

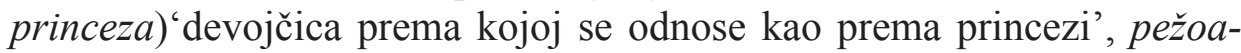


zija (Pežo + buržoazija) 'bogati ljudi koji voze skupe autompbile poput Pežoa', profaraon (profesor + faraon) 'autoritativan profesor' (primeri iz Lalić Krstin, Halupka Rešetar, 2012: 101-110). Mnogo kreativnih primera navodi i Bugarski (2014), na primer: glavabo (glava + lavabo) 'lavabo za pranje glave kod frizera', kosmetika (kozmetika + Kosmet) 'ulepšavanje stvarnosti na Kosmetu', ludala (lud + budala) 'i lud i budala', svađokusac (svađa + sladokusac) 'onaj ko uživa u svađama'. Interesantna je i pojava međujezičkih slivenica ili amalgama, kao jednog značajnog i interesantnog i nadasve kreativnog tipa srpsko-engleskih tvorenica, na koje ukazuje Rasulić (2008: 269-289). Autorka konstatuje tipove međujezičkih slivenica na osnovu specifične kombinacije elementata iz dva jezika, od kojih će ovde biti navedeni samo neki primeri kao ilustracija pomenutog fenomena: Googled (Google + ugled) 'nečiji ugled meren kroz zastupljenost ili citiranje na pretraživaču Google', McBurek (McDonald's + burek), Yutopija (Yugoslavia + utopija), COOLtura (cool + kultura), ...

\subsubsection{Složenice, polusloženice $i$ imeničke sintagme}

Teorija pojmovnog objedinjavanja veoma uspešno objašnjava i slučajeve složenica, polusloženica i sintagmi, jer sve ove strukture predstavljaju kombinacije dve reči, pa kao takve aktiviraju ulazne prostore, te dalje stapanje, koje može biti kompozitivno (npr. apple juice, srp. sok od jabuke, Ungerer and Schmid 2006: 271), ili još interesanije, nekompozitivno. U nastavku će biti dati ilustrativni primeri iz literature na engleskom jeziku, koji su prevedeni na srpski. ${ }^{7} \mathrm{Na}$ primer, imenička sintagma old friend, srp. stari prijatelj, (Ungerer, Schmid 2006: 264) nema kompozitivno značenje 'prijatelj koji je star' za razliku od sintagme star čovek, koja znači ‘čovek koji je star'. U izučavanom primeru pridev stari ne odnosi se na prijatelja, koji može biti mlad, nego na prijateljstvo, a to značenje nastaje kao rezultat procesa pojmovnog stapanja pri kome dolazi do komprimovanja različitih faza prijateljstva tokom dugog perioda i pojmovnog stapanja sa prijateljem u amalgamu. Fauconnier i Turner (2002: 100) takođe navode

7 Biće dati primeri koji u engleskom i srpskom jeziku imaju ekvivalentnu strukturu. Pri prevođenju često dolazi do razlika u pogledu strukture, npr. land yacht, srp. jahta na kopnu u značenju 'luksuzan automobil'. Takođe, u srpskom jeziku, postoje polusloženice (npr. pica-burek, veliki-mali, horor-film). 
interesantan primer sintagme, warm coat, srp. topao kaput, koja ne znači da je sam kaput topao, već da je onom ko ga nosi toplo. U pitanju je pojmovno stapanje između komprimovanog uzročno-posledičnog odnosa između kaputa i topline i pripajanje svojstva toplote kaputu. Neki od primera iz srpskog jezika čija značenja bi se mogla objasniti teorijom pojmovnog objedinjavanja jesu složenice: dangubiti, gde dolazi do stapanja aktivnosti u jednom danu i gubljenja, tj. neupražnjavanja istih, što stvara novo značenje 'lenčariti', ili starmali, gde dolazi do stapanja psihičke i intelektualne zrelosti tipične za starije ljude i uzrasne mladosti, što stvara novo značenje 'neuobičajeno zreo'. Interesantno je spomenuti i slučajeve međujezičkih srpsko-engleskih složenica, koje Rasulić (2008: 277-280) posmatra kao rezultat međujezičkog formalnog i pojmovnog stapanja, kao što su, na primer, Lav company, Profi-sun (naziv kozmetičkog salona), Doktor Filgud, City inženjering.

\subsubsection{Reči sa širokim obuhvatom značenja}

Fauconnier i Turner (2002: 25) ističu da je složena operacija pojmovnog stapanja uvek prisutna u ljudskom razmišljanju, i da se obično krije u naizgled najjednostavnijim stukturama. Kao primer navode pridev safe (srp. siguran) i razmatraju njegovo značenje u sledećim iskazima u kontekstu u kome se dete igra na plaži igra sa lopaticom: The child is safe (srp. Dete je sigurno/bezbedno), The beach is safe (srp. Plaža je sigurnal bezbedna), The shovel is safe (srp. Lopatica je bezbedna), te konstatuju da se u svim navedenim iskazima reč siguran odnosi sigurnost, tj. bezbednost deteta, a ne plaže ili lopatice. Zaključuju da se ovde značenje izvodi tako što reč siguran aktivira apstraktan mentalni prostor u semantičkom okviru OPASNOST, koji se stapa sa konkretnom situacijom ged je dete na plaži sa lopaticom, a amalgam predstavlja kontrafaktivni scenario u kome se dete povredilo (npr. lopaticom).

Filipović Kovačević (2013: 272) ovakve naizgled jednostavne reči poput siguran naziva rečima sa širokim obuhvatom značenja, i ističe da one dovode do nejasnosti budući da imaju jedno opšte značenje koje se može primeniti na više različitih domena iskustava. Na primer, reč siguran ima opšte značenje 'siguran, zaštićen od neke vrste opasnosti', pri čemu opasnosti mogu biti najrazličitijeg tipa u zavisnosti od konteksta. 
Tako, siguran u sigurna kuća znači 'zaštićen od zlostavljača', u sigurna igraonica znači 'bezbedan za malu decu, tj. nema opasnosti tipa sitnih ili oštrih predmeta, penjalice su učvršćene i sl.', ili može da znači 'da su deca stalno pod nadzorom stručnih odraslih osoba', u siguran put znači 'put u kome nema opasnosti tipa rupa na drumu, odrona, i sl'. Dakle, sa ovakvim rečima, mora se odabrati konkretan scenario, od mnogih mogućih, te zatim konstruisati, tj. izvesti, konkretno značenje. Filipović Kovačević (2013: 265-266) ovo dovodi u vezu sa pojmom nejasnosti, kada je reč upotrebljena tako da se ne može tačno ustanoviti konkretno, precizno značenje, te primalac poruke ima utisak da ne zna šta pošiljalac time tačno misli. Reči sa širokim obuhvatom značenja manifestuju semantičku nepotpunost zasnovanu na implicitnosti (videti $\S 3.3 .1$.).

\subsubsection{Kontrafaktivi}

Teorija pojmovnog objedinjavanja objašnjava i kontrafaktive, tj. jezičke strukture kojima se izražava nešto suprotno činjeničkom stanju u stvarnosti. U pitanju su kondicionalne rečenične strukture u kojima se zamišljaju alternativne mogućnosti stanja ili događaja u prošlosti ili budućnosti. Ilustrativan kontrafaktivni primer iz kognitivnolingvističke literature je sledeći: In France, Bill Clinton wouldn't have been harmed by his relationship with Monica Lewinsky (srp. U Francuskoj, Bil Klinton ne bi trpeo posledice zbog preljube sa Monikom Luinski) (Evans, Green 2006: 162-163, 406-407). Ovde se aktiviraju dva ulazna prostora. Jedan se tiče američkog političkog sistema, u kome je predsednik Klinton, koji ima ljubavnicu, Moniku Luinski, ali i krut moralni kodeks u Americi u kome se preljuba u visokim političkim krugovima osuđuje u ljudskom, ali i u pravnom smislu. Drugi prostor tiče se francuskog političkog sistema sa ulogom predsednika, ali i ljubavnice, kao i blažeg stava javnosti i pravnog sistema Francuske prema moralnosti, a konkretno preljubi predsednika. U amalgamu se stvara novo značenje, jer se projektuje semantički okvir iz prostora koji se tiče francuskog političkog sistema i odnosa prema preljubi, a u njega se uklapaju projektovani elementi iz drugog ulaznog prostora, Bil Klinton i Monika Luinski. Na taj način u kontrafaktivnom scenariju, Bil Klinton nije kažnjen u Francuskoj, a upravo svrha ovog pojmovnog amalgama jeste da naglasi ključnu razliku između jednog aspekta američ- 
kog i francuskog političkog sistema. Kao primer iz srpskog jezika mogao bi da posluži iskaz koji opisuje posledice nevaljalstva, kao što je, na primer, pljuvanje jednog dečaka: Da je Marko to uradio kod tetka Zore, ne bi se dobro proveo. Teorija pojmovnog objedinjavanja ovo bi objasnila uspostavljanjem jednog mentalnog prostora u kome je dečak, koji je pljunuo nekoga pred očima svoje bake, od koje je dobio samo grdnju, kao i drugog, zamišljenog mentalnog prostora, u kome tetka Zora, koja povremeno čuva decu, kao i znanje o njenim strogim, tradicionalnim vaspitnim principima. U trećem, amalgamskom prostoru jeste dečak koji je pljunuo, sada kod tetka Zore, ali u njenom sistemu vaspitanja on trpi stroge posledice zbog svoje neposlušnosti, na primer zabranjeno mu je druženje sa decom napolju ceo dan. Ovo značenje se konstruiše na licu mesta na osnovu složenih preslikavanja i projekcija između dva moguća scenarija, te na kraju dobijamo nov kontrafaktivni scenario.

\section{Zaključna razmatranja}

Ovaj rad donosi uporednu analizu dve važne, često suprotstavljene, kognitivnolingvističke teorije, te ciljano konstatuje, obrazlaže i ilustruje sličnosti i razlike u pojmovnim mehanizmima i tipovima pojmovno-jezičkih struktura koje dve teorije objašnjavaju. Takođe, objašnjava prednosti i nedostatke njihove primene u konkretnim tipovima pojmovno-jezičkih struktura. Pored ovoga, donosi ilustrativne primere na srpskom jeziku, što je posebno važno za teoriju pojmovne integracije, koja je u srpskoj lingvističkoj literaturi znatno manje zastupljena od pojmovne metafore. Budući da sagledava mogućnosti primene obe teorije na ilustrativnim primerima, daje ideje i smernice za buduće potencijalne pravce istraživanja.

Rezultati uporedne analize teorija pojmovnih metafora i pojmovnog objedinjavanja pokazuju da su one slične po tome što jezičke pojave koje objašnjavaju tretiraju kao pojmovne fenomene, što podrazumeva i sistematsko preslikavanje materijala između kognitivnih struktura, kao i po tome što objašnjavaju metaforičke jezičke izraze. Međutim, one se ipak značajno razlikuju po kriterijumima kao što su kognitivna shema, tip značenja, izvođenje nameravanog značenja, komunikativna svrha, pristup analizi podataka i tipične jezičke strukture. Uporedna analiza pokazuje da obe teorije objašnjavaju metaforičke izraze, pri čemu teorija pojmov- 
nih metafora na direktniji i jednostavniji način obrazlaže konvencionalne metaforičke izraze, dok teorija pojmovnog objedinjavanja ima precizniji pristup kreativnim metaforama. Pored ovoga, samo teorija pojmovnog objedinjavanja objašnjava druge aspekte mentalne i jezičke kreativnosti oličene tipično kroz morfološke slivenice, složenice, polusloženice i imeničke sintagme, reči sa širokim obuhvatom značenja i kontrafaktive. Može se zaključiti da je teorija pojmovnog objedinjavanja obuhvatnija i složenija, budući da objašnjava veći broj kognitivnih i jezičkih pojava. Pálinkás (2006: 194-195) naglašava da pojmovna integracija ima opštiju funkciju u razvijanju značenja. Rivalske teorijske razlike između ove dve teorije mogu se razrešiti prihvatanjem stava koji zastupaju Grady, Oakley i Coulson (1999) i Grady (2005), koji smatraju da se ove dve teorije nadopunjuju tako što konvencionalne metaforičke veze mogu predstavljati „gotove” veze ekvivalencije za dinamički, onlajn proces pojmovnog objedinjavanja.

\section{LITERATURA}

Ala, M., Coulson, S. (2004). The man, the key, or the car: who or what is parked out back? Cognitive Science Online, 2, 21-34.

Bauer, L. (1988). Introducing Linguistic Morphology. Edinburgh: Edinburgh University Press.

Bugarski, Ranko (2006). Žargon. Lingvistička studija. Drugo prerađeno i dopunjeno izdanje. Beograd: Biblioteka XX vek, Knjižara Krug. Bugarski, R. (2009). Nova lica jezika: sociolingvističke teme. Beograd: Biblioteka XX vek, Knjižara Krug.

Bugarski, R. (2013). Sarmagedon u Mesopotamaniji. Beograd: Biblioteka XX vek, Knjižara Krug.

Bugarski, R. (2014). Putopis po sećanju. Beograd: Biblioteka XX vek, Knjižara Krug.

Cvetković, K. (2006). Mental aWARENess perceived through the prism of our senses. In Rasulić, K., Trbojević, I. (ed), English Language and Literature Studies: Interfaces and Integrations. ELLSII75 Proceedings, volume 1 (pp. 277-284). Belgrade: Faculty of Philology.

Evans, V. (2007). A Glossary of Cognitive Linguistics. Edinburgh: Edinburgh University Press. 
Evans, V. and Green, M. (2006). Cognitive Linguistics. An Introduction. Edinburgh: Edinburgh University Press Ltd.

Filipović Kovačević, S. (2011). Anglicizmi kao međujezički pojmovni amalgami. Zbornik Matice srpske za filologiju i lingvistiku, 55/2, 239-254.

Fauconnier, G. (1985/1994). Mental Spaces. Cambridge: Cambridge University Press.

Fauconnier, G. (1997). Mappings in Thought and Language. Cambridge: Cambridge University Press.

Fauconnier, G., Turner, M. (2002). The Way We Think: Conceptual Blending and the Mind's Hidden Complexities. New York: Basic Books.

Filipović Kovačević, S. (2012). Leksičko izražavanje pojma VEOMA DOBRO u srpskom i engleskom jeziku. Zbornik Matice srpske za filologiju i lingvistiku, $54 / 2,247-263$.

Filipović Kovačević, S. (2013).Implicirana značenja u reklamama na engleskom i srpskom jeziku (E-disertacija, knjiga 5). Novi Sad: Filozofski fakultet. http://digitalna.ff.uns.ac.rs/sites/default/files/db/books/edis05_FilipovicKovacevic.pdf

Filipović Kovačević, S. (2013). Šta je važno i vredno: veliko ili malo? Iz perspektive kognitivne semantike. U I. Živančević Sekeruš (ur), Susret kultura 6. Zbornik radova, knjiga 1 (str. 525-536). Novi Sad: Filozofski fakultet.

Filipović Kovačević, S. (2015). Conceptual metaphors in English and Serbian colour idioms with red, pink, green and yellow. In S. Gudurić, M. Stefanović (ed), Jezici i kulture u vremenu i prostoru 4/1 (str. 121-133). Novi Sad: Filozofski fakultet.

Filipović Kovačević, S. (2018). Pojmovne metafore s izvornim domenom NEPROVIDNOSTI u engleskom i srpskom jeziku. Zbornik Matice srpske za filologiju i lingvistiku, 61/2, 143-160.

Grady, J. (2005). Primary metaphors as inputs to conceptual integration. Journal of Pragmatics, 37, 1595-1614.

Grady, J., Oakley, T., Coulson, S. (1999). Blending and Metaphor. In R. Gibbs, G. Steen (eds), Metaphor in Cognitive Linguistics (pp. 101-124). Philadelphia, PA: John Benjamins Publishing Company,

Halupka Rešetar, S., Lalić Krstin, G. (2009). New blends in Serbian: Typological and headedness-related issues. Godišnjak Filozofskog fakulteta, 34/1, $115-123$.

Klikovac, D. (2003). O metaforama u srpskom jeziku čiji je izvorni domen odnos SADRŽAVANJA. U D. Klikovac, 
K. Rasulić (ur), Jezik, društvo, saznanje. Profesoru Bugarskom od njegovih studenata (str. 215-238). Beograd: Filološki fakultet.

Klikovac, D. (2004). Metafore u mišljenju i jeziku. Beograd: Biblioteka XX vek: Knjižara Krug.

Kövecses, Z. (2005). Metaphor in Culture. Universality and Variation. Cambridge: Cambridge University Press.

Kövecses, Z. (2006). Language, Mind and Culture. A Practical Introduction. Oxford, New York: Oxford University Press.

Kövecses, Z. (2010). Metaphor. A Practical Introduction. Second edition. Oxford: Oxford University Press.

Kövecses, Z., Radden, G. (1998). Metonymy: Developing a cognitive linguistic view. Cognitive Linguistics, 9/1, 37-77.

Lakoff, G. (1987). Women, Fire and Dangerous Things: What Categories Reveal About the Mind. Chicago: University of Chicago Press.

Lakoff, G. (1993). The contemporary theory of metaphor. In A. Ortony (ed), Metaphor and Thought, 2nd edn. (pp. 202-251).Cambridge: Cambridge University Press.

Lakoff, G., Johnson, M. (1980/2003) Metaphors We Live By. Chicago: Chicago University Press.

Lakoff, G., Turner, M. (1989). More than Cool Reason: A Field Guide to Poetic Metaphor. New York: Mouton de Gruyter.

Langacker, R. (1987). Foundations of Cognitive Grammar, Vol. I. Stanford, CA: Stanford University Press.

Langacker, R. (1991) Foundations of Cognitive Grammar, Vol. II. Stanford, CA: Stanford University Press.

Pálinkás, I. (2006). The development of the senses: metaphorical extension or conceptual integration? Argumentum, 2, 191-197.

Panther, K., Thornburg, L. (2003) Metonymy and Pragmatic Inferencing. Amsterdam: John Benjamins.

Préić, T. (2018). Leksičko značenje između semantičke nepotpunosti i pragmatičkog upotpunjenja. U M. Radovanović, i P. Piper (ur.), Semantička proučavanja srpskog jezika. Srpski jezik u svetlu savremenih

lingvističkih teorija, knjiga 2 (str. 291-300). Beograd: Srpska akademija nauka i umetnosti.

Radden, G., Panther, K. (1999). Metonymy in Language and Thought. Amsterdam: John Benjamins. 
Radden,G. et al.(2007). Introduction. The Construction of Meaning in Language. In: G. Radden, et al. (eds), Aspects of Meaning Construction (pp. 1-15). Amsterdam and Philadelphia: John Benjamins Publishing Company.

Rasulić, K. (2003). Konceptualizacija DRUŠTVA pomoću vertikalne dimenzije. U D. Klikovac, K. Rasulić (ur), Jezik, društvo, saznanje. Profesoru Bugarskom od njegovih studenata (str. 239-254). Beograd: Filološki fakultet.

Rasulić, K. (2004). Dinamičko konstruisanje značenja: Pojmovni amalgamii pojmovne metafore. U S. Perović, V. Bulatović (ur), Lingvističke analize. Zbornik u čast 25 godina Instituta za strane jezika (str. 179-192). Podgorica: Institut za strane jezike.

Rasulić, K. (2006). This could be you: metonymy as conceptual integration. In K. Rasulić, I. Trbojević (ed). ELLSII75 Proceedings, Vol 1 (pp. 307-317). Belgrade: Faculty of Pholology.

Rasulić, K. (2008). Srpsko-engleske tvorenice u svetlu teorije pojmovne integracije. U M. Radovanović, P. Piper (ur), Semantička proučavanja srpskog jezika (str. 269-289). Beograd: Srpska akademija nauka i umetnosti.

Rasulić, K., Klikovac, D. (ur.). (2014). Jezik i saznanje. Hrestomatija iz kognitivne lingvistike. Beograd: Filološki fakultet.

Talmy, L. (2000). Toward a Cognitive Semantics (2 vols). Cambridge, MA: MIT Press.

Turner, M., Fauconnier, G. (1995). Conceptual Integration and Formal Expression. Metaphor and Symbolic Activity,10/3, 183-204.

Wierzbicka, A. (1999). Emotions across Languages and Cultures: Diversity and Universals. Cambridge, New York, Melbourne: Cambridge University Press. 
Sonja D. Filipović Kovačević

\title{
Sonja Filipović Kovačević
}

\section{CONCEPTUAL BLENDING THEORY VERSUS CONCEPTUAL METAPHOR THEORY: SPECIFIC FEATURES AND USE IN LINGUISTIC ANALYSIS}

\begin{abstract}
Summary
This paper deals with two important theories in cognitive linguistics, Conceptual Metaphor Theory, which explains conventional ways of thinking and speaking, and Conceptual Blending Theory, which focuses on mental and linguistic creativity, i.e. online construction of meaning. Since these two theories are often seen as rivals, because partly they explain the same phenomena, the general aim of this paper is to point to the specific elements of Conceptual Blending Theory in relation to Conceptual Metaphor Theory. In other words, the aim of this paper is to describe, show and exemplify the similarities, and especially differences between these two theories relating to their mechanisms, types of conceptual and linguistic structures which they account for, and the ways in which they describe them, as well as to provide key examples in Serbian. These two theories differ according to the following criteria: the cognitive schema, the type of meaning, the construction of meaning, the communicative purpose, the approach to analysis and typical linguistic structures. The contrastive analysis has shown that both theories explain metaphorical expressions, whereby Conceptual Metaphor Theory explains conventional metaphors more directly and easily, while Conceptual Blending Theory accounts more precisely for creative metaphors. In addition to this, Conceptual Blending Theory alone explains other aspects of mental and linguistic creativity typically in the form of morphological blends, compounds, nominal phrases, vague words and counterfactuals.
\end{abstract}

Key words: Conceptual Metaphor Theory, Conceptual Integration Theory, similarities, differences, conventionality, creativity, linguistic structures. 